Niniejsza publikacja jest dostęna na licencji Creative Commons. Uznanie autorstwa-Użycie niekomercyjne-Bez utworów zależnych 3.0 Polska. Pewne prawa zastrzeżone na rzecz autora. Zezwala się na wykorzystanie publikacji zgodnie z licencja - pod warunkiem zachowania niniejszej informacji licencyjnej oraz wskazania autora jako właściciela praw do tekstu. Treść licencji jest dostępna na stronie: http://creativecommons.org/licenses/by-nc-nd/3.0/pl/

Lingwistyka Stosowana 21: 1/2017, 83-94

\author{
Jan Bolesław LOMPIEŚ \\ Uniwersytet Warszawski
}

\title{
Uwagi o metapoznaniu, metawiedzy i metakompetencji
}

\begin{abstract}
:
Remarks on metacognition, metaknowledge and metacompetence

The aim of this paper is to give an overview of the most important approaches to the concepts of metacognition, metaknowledge and metacompetence. A growing body of research on these concepts highlights the significance and benefits of acquiring metacognitive knowledge and competence, especially in education and learning. Though scholarly opinion is still divided as to their exact functions and definitions, it is generally acknowledged that these multifaceted concepts are closely connected with higher order skills that result in a form of executive control involving self-monitoring, self-assessment and self-regulation. These skills are now extremely important in view of the fact that, according to some reports, education has failed to prepare students for the challenges of the $21^{\text {st }}$ century. The author also presents his approach to the construct of (meta)knowledge and (meta)competence, focussing on the role of language as the main contributing factor in the process of knowledge acquisition. Finally, the author discusses various aspects of competence demands within the community of scholars.
\end{abstract}

\section{Wstęp}

Jeśli prawdą jest, że Sokrates istotnie wygłosił słynne słowa „wiem, że nic nie wiem" i tym samym uznał niedostatek własnej wiedzy, to być może chciał w ten sposób pokazać, że drogą do poznania i wiedzy jest także świadomość obszarów swojej niewiedzy. Są to jednak tylko przypuszczenia, gdyż - jak wiadomo - Sokrates nie pozostawił po sobie tekstów pisanych. W swej „Historii Filozofii” W. Tatarkiewicz pisze o nim, że ,gdy inni ulegając złudzeniu mniemali, że wiedzę posiadają, on miał świadomość swojej niewiedzy i nazywał to wiedzą o niewiedzy" (1970: 63). Być może Sokrates uznawał, że wgląd w obszary własnej wiedzy i niewiedzy ma istotne znaczenie dla ludzkiego poznania, a jeśli tak, to można go chyba uznać za jednego z pierwszych, którzy dostrzegli znaczenie tzw. metawiedzy.

Refleksja na poziomie meta, rozumiana jako zbiór czynności kognitywnych wyższego rzędu, mających charakter metapoznawczej refleksji i prowadzących do metawiedzy, była uprawiania przez filozofów od czasów najdawniejszych, także w wielu innych kulturach. Zapiski z rozmów Konfucjusza z uczniami kilkukrotnie podnoszą temat takiej refleksji. W rozmowach z uczniami Konfucjusz mówi, że „,to, 
czego nie wiemy, i wiedza o tym, czego nie wiemy, to jest właśnie prawdziwa wie$\mathrm{dza}^{1}$.

Wiedza, na temat której rozważania toczyły się od zarania ludzkości, odnoszona była początkowo do filozoficznych rozważań nad wiedzą w powiązaniu z cnotą, sprawnością działania i teleologią i jej głębsza analiza, jak stwierdza to J. Hartman (2007: 168) „datuje się od Leibnitza i dojrzewa u Kanta i Fichtego”.

Obecnie prefiks meta w dyskursie naukowym wielu nauk oznacza refleksję poznawczą wyższego rzędu i ogląd rzeczywistości z pewnego dystansu, z zewnętrznej perspektywy wobec danego zagadnienia, stanu rzeczy lub badań nad np. nauką jako tzw. metanauką lub nad jej dyscyplinami szczegółowymi. Nie zawsze jednak tak było, u Arystotelesa prefiks meta (oznaczający w jęz. greckim „,po, poza”) odnosił się do dzieła znajdującego się po innym dziele. Po traktacie pt. „Fizyka” następował u niego traktat „Metafizyka”.

W ślad za F. Gruczą możemy mówić o metanauce ogólnej i metanaukach szczegółowych (zob. F. Grucza 1983: 131-132). Przedrostek meta rozpowszechnił się i poprzedza obecnie wiele nazw i terminów, takich jak metawiedza, metapoznanie, metakompetencja i inne. Na marginesie warto podkreślić, że znajdujące się w tytule i w treści artykułu wyrażenia te są użyte w znaczeniu wytworów, nie zaś czynności. Natomiast termin metapoznanie, zgodnie z definicją jego twórcy, J. Flawella, używany jest w znaczeniu czynności i procesów myślowych.

W polskiej literaturze filozoficznej i psychologicznej zagadnienia metapoznania były w połowie ubiegłego stulecia przedmiotem rozważań wybitnych przedstawicieli tych dyscyplin, m.in. K. Ajdukiewicza w odniesieniu do refleksji nad nauką, E. Grodzińskiego (jako mowa wewnętrzna) oraz J. Kozieleckiego (jako samowiedza).

W ostatnim okresie temat refleksji metapoznawczej, metafilozofii i metakompetencji podjął m.in. R. Jakiel (zob. R. Jakiel 2015), a także J. Hartman w swoich licznych artykułach i monografiach.

W obrębie językoznawstwa tym, który jako jeden z pierwszych zapoczątkował analizę zagadnień metapoznawczych i refleksji typu meta był F. Grucza w artykule Metasprachen, Kodematik, Fremdsprachenunterricht (1967), którą to analizę kontynuował w dalszych swoich pracach naukowych. Badania nad zagadnieniami typu meta są kontynuowane głównie w obrębie dyscyplin szczegółowych, zwłaszcza psychologii i pedagogiki oraz jako badania metaglottodydaktyczne (por. m.in. J. Bańczerowski, W. Wilczyńska, A. Michońska-Stadnik, M. Białecka-Pikul, I. Orchowska, D. Zdybel). Warto zwrócić uwagę na tak ważny postulat J. Bańczerowskiego o konieczności prowadzenia badań metaglottodydaktycznych, które uważał za warunkujące rozwój glottodydaktyki (1975: 21 za I. Orchowska 2015: 171).

Jak już wspomniano, za twórcę terminu metapoznanie (metacognition) jest uważany J. Flavell, który w latach siedemdziesiątych ubiegłego wieku wprowadził termin metapoznanie na określenie procesów myślowych wyższego rzędu odnoszących

\footnotetext{
${ }^{1}$ Ce qu'on ne sait pas, savoir qu'on ne le sait pas: c'est savoir véritablement (Confucius 2000).
} 
się do kontrolowania i regulowania podstawowych procesów poznawczych, w tym zwłaszcza procesów nabywania wiedzy. J. Favell (1979) podkreślał ogromne znaczenie ludzkich zdolności metapoznawczych. Uważał, że autorefleksja i dążenie do samopoznania na poziomie meta spełniają ważne funkcje regulujące i monitorujące rozwój jednostki ludzkiej. Uważał on, że dzięki autorefleksji człowiek może wniknąć w głąb swoich myśli i przeanalizować je po to, aby następnie podjąć odpowiednie działania regulujące i naprawcze. Akt refleksji metapoznawczej można traktować jako odrębny akt poznawczy - w najnowszych badaniach akt taki jest uważany za kwintesencję metapoznania (zob. P. Tarricone 2011).

W bardzo wielu pracach naukowych dotyczących metapoznania, które pojawiły się w ostatnich dwóch dekadach, termin ten jest jednak wciąż przedmiotem sporów wśród członków społeczności akademickiej. Według P. Tarricone (2011) jedną z najbardziej znanych teorii metapoznania jest teoria opracowana przez A. Efklides (2008), według której metapoznanie jest złożonym procesem monitorowania i kontroli własnych procesów poznawczych, doświadczeń i przeżyć, a także wiedzy i umiejętności.

\section{Zwrot metapoznawczy (metacognitive turn) jako nowy trend w badaniach nad poznaniem}

Zagadnienie metapoznania budzi wciąż ogromne zainteresowanie naukowców z wielu dyscyplin. Wynika to $\mathrm{z}$ coraz powszechniejszego uznania faktu, że sama wiedza przedmiotowa nie wystarcza i w dzisiejszych czasach coraz większa jest potrzeba głębszej i krytycznej refleksji, która prowadziłaby do kontroli i sterowania dalszym rozwojem własnej wiedzy i kompetencji. Najnowsze opracowania podkreślają potrzebę przeniesienia akcentu $\mathrm{z}$ kształcenia przedmiotowego na kształcenie metaprzedmiotowe i na aspekt metapoznawczy. To przeniesienie akcentu jest nawet określane jako zwrot metapoznawczy (por. N. Silver 2013), analogicznie do zwrotów, które zapoczątkowały wcześniejsze etapy rozwoju niektórych nauk humanistycznych (np. zwrot pragmatyczny czy zwrot kognitywny).

$\mathrm{Na}$ potrzebę takiego zwrotu i przeniesienia akcentów w dziedzinie edukacji wskazuje raport grupy naukowców z Michigan State University (zob. K. Kereluik et al. 2013), którzy w uzasadnieniu wymieniają m.in. następujące czynniki powodujące konieczność dokonania zmian:

- dynamika i złożoność przemian i rozwoju w nauce i gospodarce (także w wyniku pogłębiającej się globalizacji oraz cyfryzacji i robotyzacji),

- wynikająca z wyżej wymienionych przemian nieustannie rosnąca lawina informacji, która przeciąża układ kognitywny jednostek, z czego wynika konieczność kształtowania kompetencji typu meta w zakresie tzw. data mining, identyfikacji i rozróżniania danych znaczących, ważnych i wysokiej jakości. Umiejętność takiej identyfikacji i trafnej oceny danych i informacji staje się obecnie ważną umiejętnością metapoznawczą.

Wspomniana dynamika przemian we współczesnym świecie i rosnąca złożoność procesów gospodarczych, naukowych i technicznych, zachodzących w wyniku rewolucji cyfrowej, robotyzacji i dominacji Internetu leżały u podstaw takich wnio- 
sków. W raporcie powtórzono oczywistą prawdę, że przy obecnym tempie tych zmian należy zakładać, że już obecnie żadna najlepsza nawet uczelnia na świecie nie uzbroi studentów w wiedzę ani tym bardziej w kompetencje, które wystarczą im do końca życia.

We wspomnianym raporcie naukowców amerykańskich podkreśla się mocno (zob. K. Kereluik et al. 2013: 128), że dynamika tych przemian stawia pod znakiem zapytania zdolność systemu kształcenia akademickiego do nadążania za postępem dokonującym się szybko w wielu obszarach gospodarki, nauki i techniki. Wreszcie $\mathrm{w}$ wyniku tych przemian, zwłaszcza w sferze złożoności procesów produkcji, technologii i nauki, nastąpią zmiany strukturalne na rynku pracy, które będą przejawiać się w zwiększonym zapotrzebowaniu na pracowników o najwyższych i specjalistycznych kwalifikacjach.

Świadomość tego leżała u podstaw tezy o konieczności nieustającego kształcenia przez całe życie. Teza ta znalazła odzwierciedlenie w pracach Komisji Europejskiej i jej centrów badawczych (JRC - Joint Research Centre oraz CRELL - Centre for Research on Lifelong Learning), których celem było opracowanie ogólnoeuropejskich ram i narzędzi do pomiaru „kompetencji uczenia się uczenia” (za: D. Zdybel 2015: 58). W pracach tych i innych instytucji europejskich za istotę aspektu metapoznawczego uznano skłonność do podejmowania refleksji nad własnymi zdolnościami uczenia się, głębię i dokładność tej refleksji, a także zaufanie do własnych możliwości w tym zakresie, przekonanie oraz wiarę w możliwość osiągnięcia sukcesu (ibidem).

W dobrze pojętym własnym interesie pracownicy powinni więc rozwijać swoje kompetencje metapoznawcze $\mathrm{w}$ celu identyfikacji własnych deficytów wiedzy i kompetencji, aby odpowiednio kierować własnym rozwojem zawodowym oraz podnoszeniem kompetencji i wiedzy w deficytowych obszarach. Wyniki badań świadczą o tym, że metapoznanie, w tym autorefleksja uważana za podstawowy komponent czynności metapoznawczych, jest jednym z najsilniejszych czynników prognozujących efektywność procesu uczenia się (por. D. Zdybel 2015: 55). Zaś złożony charakter szybko zmieniającej się współczesnej rzeczywistości czyni koniecznym szybkie i efektywne uczenie się nowo powstających zjawisk, aby w drodze zarządzania własnymi kompetencjami sprostać wymogom tej rzeczywistości.

\section{Metawiedza i metakompetencja}

Metawiedza, w najogólniejszym sformułowaniu, oznacza wiedzę konkretnej osoby o stanie własnej wiedzy. Metawiedzę, podobnie jak wiedzę, traktujemy jako immanentną, aczkolwiek zmienną, właściwość mózgu konkretnej jednostki ludzkiej. W rozważaniach naszych abstrahujemy od ludzkiej wiedzy genetycznej i uważamy metawiedzę za rezultat procesów wytwarzania tej wiedzy w drodze pracy metapoznawczej i autorefleksji nad jakościowym stanem wiedzy niższego rzędu (wiedzy przedmiotowej). Taka autorefleksja jest wglądem z pewnego dystansu, jak gdyby z zewnątrz $\mathrm{w}$ stan wiedzy własnej przedmiotowej. J. Woleński pisze na ten temat: „Każda autorefleksja nad własną wiedzą, np. dociekanie, co z niej wynika, sprawia, 
że podmiot, aczkolwiek bada sam siebie, zajmuje postawę de alio" (zob. J. Woleński 2005: 379).

Konstrukt zwany kompetencją jest niejednolitym i wciąż dyskusyjnym zbiorem podsystemów wiedzy i umiejętności, jakie konkretna jednostka ludzka jest w stanie wytworzyć. Z kolei umiejętność jest konstruktem teoretycznym oznaczającym dyspozycję do efektywnego/skutecznego przeprowadzania zorganizowanych czynności poznawczych lub poznawczo-motorycznych mających na celu wykonanie określonego zadania (zob. Z. Chlewiński 1992: 161). Oczywiście różne typy zadań wymagają różnych umiejętności. Do istoty umiejętności należy sprawne posługiwanie się wiedzą i doświadczeniem.

W obrębie kompetencji jednostki jako konstruktu teoretycznego, można wyróżnić kompetencję odtwórczą (inaczej zachowawczą lub reproduktywną), w której pierwiastek twórczy nie odgrywa znaczącej roli, oraz kompetencję twórczą, w którą wmontowany jest komponent heurystyczny decydujący o zdolności jednostki do tworzenia nowej jakościowo wiedzy, metod i osiągania ulepszonych wyników działania (por. J. Hartman 2007: 169). Dynamiczny rozwój i przemiany w gospodarce i technice, o których wcześniej była mowa, tworzą zapotrzebowanie na jednostki o wysokiej kompetencji oraz (meta)kompetencji twórczej, czyli wyposażonej w komponent heurystyczny, który będzie wspomagać umiejętności dotyczące identyfikowania własnego potencjału twórczego i jego deficytów oraz stymulowania także jego rozwoju, a nie tylko kompetencji zachowawczej.

Szczególną rolę w procesach zarówno wytwarzania (meta)wiedzy, jak i (meta)kompetencji spełnia język, który warunkuje te procesy generowania wiedzy i jest podstawowym współczynnikiem determinującym tworzenie ludzkiej wiedzy (por. S. Grucza 2015: 67). Wiedza musi być ujęzykowiona, zresztą nie ma innego sposobu, aby wykazać się posiadaną wiedzą i jej jakością poza przedstawieniem dowodów w postaci eksponentów językowych tej wiedzy, czyli tekstów ustnych lub pisanych. Celnie wyraził to M.A. Krąpiec: „Myśl i idee tak długo pozostaną niejasne, jak długo nie zostaną wyraźnie sformułowane w słowach" (1995b: 33). Poniżej przedstawiam schemat hierarchiczny typów i poziomów wiedzy ludzkiej wykorzystywanej na różnych poziomach pracy poznawczej jednostki.

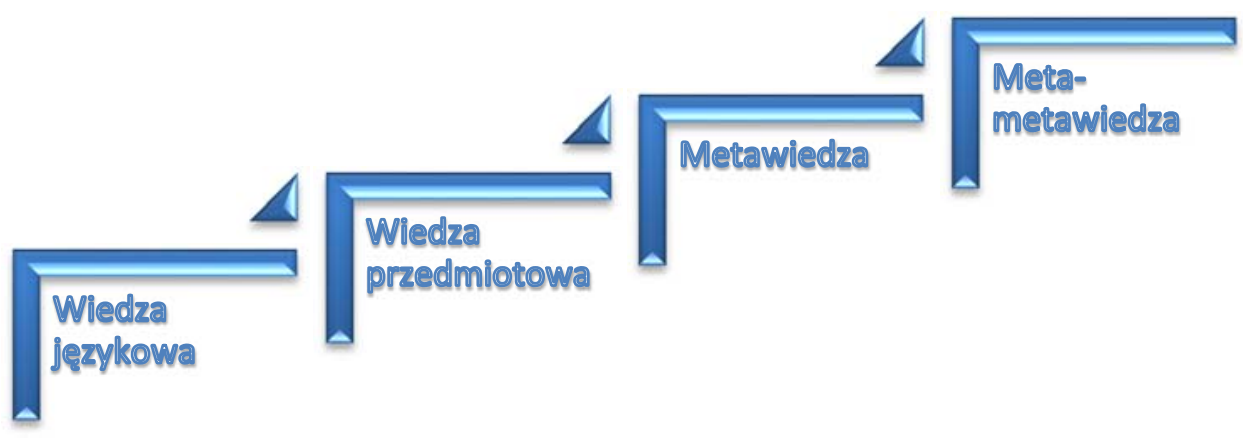

Rysunek 1. Typy i poziomy wiedzy w toku pracy poznawczej czlowieka. 
Wiedza językowa jest tym zakresem wiedzy, który posiada wyjątkowe znaczenie dla pracy poznawczej dzięki temu, że, po pierwsze, umożliwia wyrażanie i transferencję wiedzy oraz, po drugie, umożliwia wytwarzanie wiedzy dzięki swej funkcji epistemicznej (por. S. Grucza 2015: 65). Im głębsza jest wiedza językowa, tym większe są możliwości transferencyjne i kognitywne jednostki ludzkiej. Warto przytoczyć w tym kontekście stwierdzenie F. Gruczy (1991: 34) na temat funkcji kognitywnej samych tylko terminów:

(..) nie jest prawdą, żeby (...) funkcja terminów sprowadzała się jedynie do funkcji etykietowania pojęć. Ich prymarna i zarazem główna rola polega na tym, że są one narzędziami mentalnego przetwarzania świata, czyli najpierw narzędziami wytwarzania i zarazem przetwarzania informacji o świecie, tworzenia i przekształcania mentalnego i intelektualnego obrazu świata, a następnie także urzeczywistniania tego ostatniego.

Wiedza przedmiotowa jest wiedzą o właściwościach badanych obiektów rzeczywistości. Z kolei metawiedza jest wiedzą analityczną o jakościowych aspektach wiedzy przedmiotowej, w tym o środkach, procesach, celach, strategiach i rezultatach badawczych.

Znana badaczka zagadnień metapoznania D. Kuhn twierdzi, że skoro w badaniach nad poznaniem rozróżnia się wiedzę proceduralną (wiedzę jak) oraz wiedzę deklaratywną (wiedzę że), to prawdopodobnie na poziomie operacji „meta-” można również odróżnić te dwa rodzaje poznawania. Proceduralne metapoznawanie byłoby, zdaniem tej autorki, poznawaniem metastrategicznym (metastrategic knowing), które autorka definiuje jako „metapoznawanie dotyczące proceduralnego poznawania" (2000: 179, za: M. Białecka-Pikul 2012: 234-235).

Następnie, według D. Kuhn, poznawanie metastrategiczne można podzielić na wiedzę metazadaniową (metatask knowledge), czyli wiedzę o celach zadania, oraz wiedzę metastrategiczną (metastrategic knowledge), czyli wiedzę o strategiach służących do osiągnięcia tych celów. Zdaniem Białeckiej-Pikul (2015) można stwierdzić, w ślad za D. Kuhn (2000), że dotyczy to budowania wiedzy o strategiach poznawczych, to jest wiedzy, która sama ma charakter metastrategii. Według opinii D. Kuhn, metastrategiczne poznawanie jest procesem osiagania stopniowej kontroli nad procesami poznawczymi, co polega na osiąganiu zdolności do samodzielnego inicjowania lub hamowania pewnych procesów i działań. D. Kuhn podkreśla, że jako pierwszy tak rozumianą kontrolę poznania opisał L. Wygotski. Trzeba, oczywiście, dodać, że nie nazywał tego metapoznaniem ani metastrategią. Wskazał na to zjawisko przy okazji m.in. omawiania mowy wewnętrznej określanej przez niego jako myślenie werbalne, które służy celom orientacji intelektualnej, uświadomienia i pokonywania trudności, celom zrozumienia i myślenia (zob. L. Wygotski 1989: 351, 396 i nast.).

Wreszcie meta-metawiedza jest wiedzą wyższego rzędu, obejmującą np. ocenę skuteczności procesów, strategii oraz trafności sądów niższego poziomu, tj. metawiedzy.

W praktyce praca poznawcza przebiega z wykorzystaniem wiedzy językowej, wiedzy przedmiotowej i metaprzedmiotowej na następujących trzech poziomach:

a) na poziomie językowym, 
b) na poziomie podstawowych procesów poznawczych (percepcja, pamięć, interpretacja podstawowych danych przedmiotowych),

c) na poziomie meta, na którym jednostka obejmuje kontrolę metapoznawczą i monitorującą z udziałem wiedzy i doświadczeń metapoznawczych.

Według T.O. Nelson i L. Narens (1990: 127; za: D. Zdybel 2015: 62) w toku refleksji na poziomie meta pojawia się informacja o tym, co dzieje się na poziomie obiektu (przedmiotowym), w tym: jakie procesy poznawcze zostały uruchomione, w jakim tempie przebiegają, czy napotykają na przeszkody, bariery, na ile ich realizacja jest płynna i efektywna. W tym znaczeniu można powiedzieć, że monitorowanie jest procesem ,przyglądania się sobie”, czy też raczej wsłuchiwania się we własne myślenie po to, aby na podstawie zdobytych tą drogą informacji zbudować model reprezentację poznawczą umożliwiającą świadome regulowanie przebiegu własnych myśli, stosownie do przyjętych celów i założeń. Procesy kontroli metapoznawczej przebiegają analogicznie do mówienia do słuchawki telefonicznej - tą drogą poziom meta modyfikuje uruchomione procesy poznawcze, podejmując strategiczne decyzje dotyczące kontynuowania, zmiany kierunku, tempa czy charakteru, bądź przerwania aktywności (zob. T. Nelson/ L. Narens 1990: 127, za: D. Zdybel 2015: 62).

Każda wiedza jest wynikiem pracy poznawczej i metapoznawczej konkretnej jednostki ludzkiej, na którą składa się sekwencja aktów (meta)poznawczych. Właściwy akt poznawczy jest, według M.A. Krąpca (1995a, za: W. Chudy 1981: 194195), poprzedzany tzw. aktem prerefleksyjnym, nazywanym przez niego aktem ,egzystencjalnym", który nie jest właściwym aktem poznawczym. Jest jedynie powierzchownym, spontanicznym i bezrefleksyjnym aktem stwierdzającym istnienie (egzystencję) badanej rzeczywistości. W ogromnej większości przypadków jednostka poprzestaje na tym etapie poznania przedmiotowego, nie podejmując głębszej refleksji na poziomie meta.

Zdaniem F. Gruczy głębsza refleksja związana z wejście na poziom meta nie zmienia charakteru ani struktury pracy poznawczej, w której także występuje człon diagnostyczny, anagnostyczny i prognostyczny (zob. F. Grucza 1983: 132). Człon diagnostyczny odnosi się do stanu badanej rzeczywistości, o której zakładamy, że istnieje. Człon anagnostyczny dotyczy stanu rzeczywistości, o której zakładamy, że istniała. Natomiast człon prognostyczny odnosi się do wiedzy o stanach rzeczy, które według naszych założeń będą istniały, czyli jest to mniej lub bardziej pewna wiedza o przyszłości. Wiedza o przyszłości i tzw. prognozowanie jutra nabiera obecnie coraz większego znaczenia (por. S. Grucza 2015: 58 i nast.).

Na poniższym rysunku przedstawiam omawiane typy wiedzy oraz relacje hierarchiczne między nimi. 


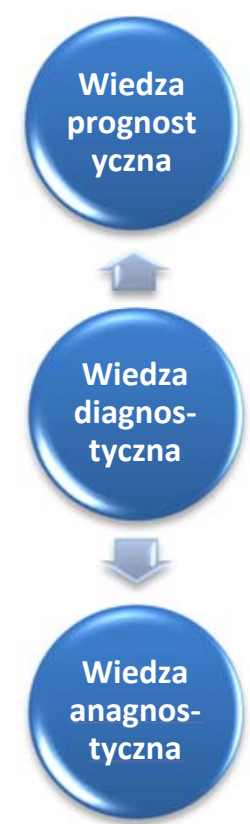

Rysunek 2. Podstawowe typy wiedzy i relacje hierarchiczne między wiedza diagnostyczna, anagnostyczna i prognostyczna (za: F. Grucza 1983: 77 i S. Grucza 2015: 60).

Jeśli droga do wiedzy diagnostycznej prowadzi przez obserwację, refleksję i diagnozę (por. F. Grucza 2007: 143 i nast.), to per analogiam droga do metawiedzy diagnostycznej wiedzie przez autoobserwację, autorefleksję i autodiagnozę. W wielu teoriach autorefleksja jest uważana za podstawowy czynnik rozwojowy, dynamizujący proces kształtowania rozwoju jednostki i budowania jej kompetencji.

\section{Praca (meta)poznawcza i tekstotwórcza naukowca}

Naukowiec musi swoją wiedzę werbalizować w różnych okolicznościach ustnie i pisemnie $\mathrm{w}$ toku pracy poznawczej i transferencyjnej wykonywanej dla różnych grup odbiorców. Dlatego też, obok kompetencji poznawczych sensu stricto, niezbędnym, a właściwie najbardziej niezbędnym, komponentem całkowitej kompetencji człowieka nauki jest jego kompetencja tekstotwórcza, którą aktywizuje on w toku werbalizacji wiedzy i tworzenia tekstu. Umiejętność tworzenia tekstu, zwłaszcza tekstu pisanego, jest cenną i potrzebną umiejętnością w świecie nauki, ale jest to także złożona czynność kognitywna, którą naukowiec podejmuje w każdej fazie swojej pracy poznawczej. Poniższy schemat przedstawia cztery ogniwa pracy poznawczej diagnostycznej. 


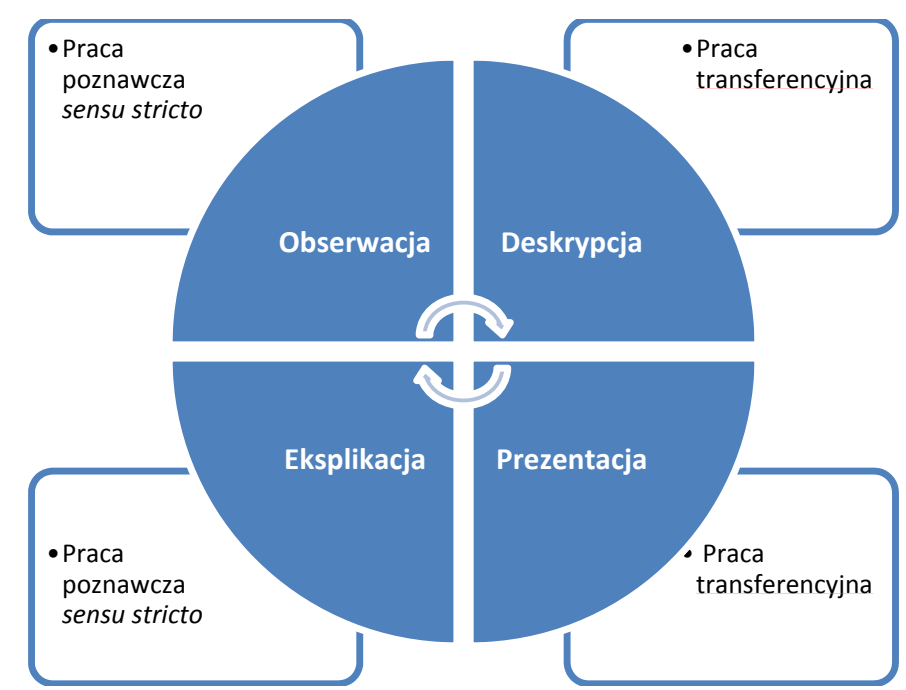

Rysunek 3. Ogniwa pracy poznawczej diagnostycznej (na podstawie: F. Grucza 2007: 143-155).

Praca transferencyjna mniej nas w tej chwili interesuje, natomiast w obrębie pracy poznawczej sensu stricto istotny jest podział na obserwację i eksplikację. Pierwsze ogniwo pracy poznawczej, według F. Gruczy (2007: 144), wydaje się obejmować akty poznawcze wyróżnione przez M.A. Krąpca jako egzystencjalne, gdyż obejmują następujące pytania:

- czy wyróżnione obiekty istnieją lub istniały naprawdę?

- jak i gdzie wyróżnione obiekty istnieją lub istniały?

Dopiero kolejne pytania w tym ogniwie pracy poznawczej sięgają głębiej do cech i właściwości tych obiektów, są więc pytaniami typowo poznawczymi. W odniesieniu natomiast do ogniwa eksplikacji, to na tym etapie konieczna jest wnikliwa refleksja nad wyróżnionymi obiektami i ich cechami zidentyfikowanymi na poprzednim etapie, tak aby odpowiedzieć na głębiej sięgające pytania typu „dlaczego” (na przykład, dlaczego obiekty badane mają takie a nie inne właściwości lub dlaczego zachodzą między nimi takie a nie inne relacje itp.). Proces eksplikacji jest już pracą poznawczą na poziomie meta, która wymaga wysokiego poziomu metakompetencji podmiotu nauki.

Powracając do pracy transferencyjnej, niewątpliwie największe znaczenie przy jej wykonywaniu ma wspomniana wcześniej kompetencja tekstotwórcza człowieka nauki. Jej zasadniczymi komponentami są kompetencja językowa, kompetencja dyskursywna i kompetencja interkulturowa. Te trzy subkompetencje, przedstawione na poniższym rysunku, współdziałają ze sobą i wspomagają podmiot nauki w toku jego pracy transferencyjnej. 


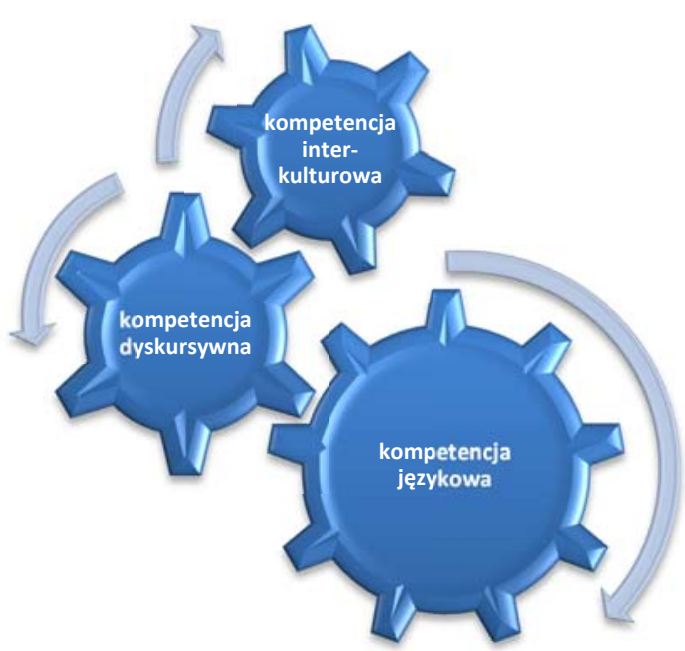

Rysunek 4. Kompetencja tekstotwórcza a jej główne komponenty (w oparciu o: S. Grucza 2008: 154 i nast.).

$\mathrm{Na}$ rysunku tym kompetencja językowa jest głównym kołem napędowym kompetencji dyskursywnej i interkulturowej, które łącznie stanowią zasadnicze komponenty kompetencji tekstotwórczej. W środowisku naukowym podmiot nauki musi swoją wiedzę eksternalizować skutecznie w postaci tworzenia tekstów ustnych i pisanych, co wymaga wysokiego poziomu kompetencji tekstotwórczej w odniesieniu do każdego z jej trzech elementów.

W tym miejscu warto powrócić do raportu naukowców z Michigan State University, o którym wspomniałem wcześniej, aby przedstawić ich prognozy odnoszące się do kompetencji niezbędnych u człowieka XXI wieku. Otóż prognozy te dotyczą koniecznych w coraz większym stopniu kompetencji interkulturowych. Wiąże się to ze wzrostem globalizacji, dostępności nowych technologii, dzięki którym przedstawiciele odmiennych kultur będą w stopniu dotychczas niespotykanym mieć możliwość kontaktu i współpracy. Stąd rosnąca jest rola kompetencji interkulturowej, w tym także dla przedstawicieli społeczności akademickich na świecie. Niezależnie od kompetencji kulturowej, szczególnie wysokie wymogi kompetencyjne są stawiane wobec tych członków społeczności, którzy decydują się na publikowanie w uznanych czasopismach naukowych za granicą i na prezentacje podczas konferencji zagranicznych.

Ten wątek kompetencji członków społeczności akademickiej przewinął się blisko dziesięć lat temu w artykule J. Hartmana (2007), o którym tylko wspomnę. Otóż J. Hartman wyraził w tym artykule przekonanie, iż obecnie szczególnym wyzwaniem naszych czasów jest analiza i wytworzenie pewnej, jak to nazywa, ,negatywnej metakompetencji” decydującej o umiejętności zarządzania niekompetencją (2007: 160). W tym pojęciu zawiera się, jak to wyjaśnia, umiejętność rozpoznawania niekompetencji i neutralizacji jej szkodliwych skutków (ibidem). J. Hartman, bazując zapewne na swojej znajomości środowiska akademickiego filozofów, krytycznie ocenia kompetencje członków środowiska akademickiego i nie tylko akade- 
mickiego. Uważa on, że istnieje kryzys kompetencji i kryzys samooceny, których przezwyciężenie jest jednym z największych wyzwań intelektualnych naszych czasów (ibidem).

\section{Uwagi końcowe}

Zamierzałem w ogromnym skrócie przedstawić istotę metawiedzy, metakompetencji i znaczenie czynności metapoznawczych. Badania nad tymi zagadnieniami rozwijają się dynamicznie zwłaszcza w odniesieniu do procesów uczenia się. Wobec dynamicznych przemian, jakie obserwujemy w wielu dziedzinach i ich negatywnych skutków dla wartości uzyskiwanego obecnie wykształcenia, pewnym środkiem zaradczym może stać się kształcenie kompetencji metapoznawczych, które mogłyby umożliwić identyfikowanie oraz ocenę poziomu i ew. deficytów własnej wiedzy oraz sterowanie rozwojem własnej wiedzy i kompetencji stosownie do zmieniających się potrzeb. Jak twierdzi D. Zdybel (2015: 58), w nowoczesnym społeczeństwie wiedzy bowiem kluczem do sukcesu jest nie tyle wiedza o tym, jak nauczyć się konkretnych treści (czy zdać egzamin z konkretnego przedmiotu), ale raczej wiedza o tym, jak przebiega moje własne uczenie się, na jakie bariery i blokady natrafia i na ile przynosi oczekiwane rezultaty.

\section{Bibliografia}

Białecka-Pikul, M. (2012), Narodziny i rozwój refleksji nad myśleniem. Kraków.

Chlewiński, Z. (1992), Ksztattowanie się umiejętności poznawczych. (w:) M. Materska/ T. Tyszka (red), Psychologia i poznanie. Warszawa, 161-178.

Chudy, W. (1981), Zagadnienia tomistycznej teorii sądów egzystencjalnych (artykut polemiczno-wyjaśniajacy), (w:) Studia Philosophiae Christianae, 17 (1), 185-200.

Confucius (2002), Entretiens du Maître avec ses disciples. Paris/Kindle Edition.

Efklides, A. (2008), Metacognition. Defining its facets and levels of functioning in relation to self-regulation and Co-regulation. (w:) European Psychologist, 13 (4), 277-287.

Flavell, J.H. (1979), Metacognition and Cognitive Monitoring: A new area of cognitive-developmental inquiry. (w:) American Psychologist, 34 (10), 906-911.

Grucza, F. (1967), Metasprachen, Kodematik, Fremdsprachenunterricht. (w:) Glottodidactica, 2, 11-21.

Grucza, F. (1983), Zagadnienia Metalingwistyki. Lingwistyka - jej przedmiot, lingwistyka stosowana. Warszawa.

Grucza, F. (1991), Terminologia - jej przedmiot, status i znaczenie, (w:) F. Grucza (red.), Teoretyczne podstawy terminologii. Wrocław, 11-43.

Grucza, F. (2007), Lingwistyka stosowana. Historia - zadania - osiagnięcia. Warszawa.

Grucza, S. (2008), Lingwistyka języków specjalistycznych. Warszawa. 
Grucza, S. (2015), Języki jako instrumenty predykcji wiedzy przyszłości, (w:) A. Duszak/ A. Jopek-Bosiacka/ G. Kowalski (red.), Tekst naukowy i jego przekład, Kraków, 53-78.

Hartman, J. (2007), Prolegomena do teorii kompetencji, (w:) J. Gąssowski/ J. Goćkowski/ K.M. Machowska (red.), Problemy cywilizacyjne naszej współczesności. Pułtusk, 159-170.

Jakiel, R. (2015), Kilka uwag o naukowej refleksji wyższego rzędu, (w:) Tekstoteka Filozoficzna nr 4/2015, 6-13.

Kereluik, K./ P. Mishra/ C. Fahnoe/ L. Terry (2013), What Knowledge Is of Most Worth: Teacher Knowledge for $21^{\text {st }}$ Century Learning, (w:) Journal of Digital Learning in Teacher Education, 29 (4), 127-140.

Kozielecki, J. (1986), Psychologiczna teoria samowiedzy. Warszawa.

Krąpiec, M.A. (1995a), Metafizyka. Zarys teorii bytu .Lublin.

Krąpiec, M.A. (1995b), Język i świat realny. Lublin.

Kuhn, D. (2000), Metacognitive development, (w:) Current Directions in Psychological Science, 9 (5), 178-181.

Nelson, T.O./ L. Narens (1990), Metamemory: a theoretical framework and new findings, (w:) G.H. Bower (red.), The psychology of learning and motivation, 26, 125-173.

Orchowska, I. (2015), De la nécessité des recherches méta-glottodidactiques au sein de la communauté polonaise des spécialistes dans l'enseignement/apprentissage des langues étrangères, (w:) Glottodidactica, XLII (2), 169-184.

Pena-Ayala, A. (red.) 2015, Metacognition: Fundaments, Applications, and Trends. A Profile of the Current State-Of-The-Art. Cham/Heidelberg.

Silver, N. (2013), Reflective Pedagogies and the Metacognitive Turn in College Teaching, (w:) M. Kaplan et al. (red.), Using Reflection and Metacognition to Improve Student Learning. Sterling/ Virginia, 1-7.

Tarricone, P. (2011), The Taxonomy of Metacognition. Howe/ New York.

Tatarkiewicz, W. (1970), Historia Filozofii. Tom pierwszy. Filozofia starożytna $i$ średniowieczna. Warszawa.

Wilczyńska, W./ A. Michońska-Stadnik (2011), Metodologia badań w glottodydaktyce. Kraków.

Woleński, J. (2005), Epistemologia. Poznanie, prawda, wiedza, realizm. Warszawa.

Wygotski, L.S. (1989), Myślenie i mowa. Warszawa.

Zdybel, D. (2015), Metapoznanie - ukryty wymiar kompetencji uczenia się, (w:) J. Uszyńska-Jarmoc/ M. Bilewicz (red.), Kompetencje kluczowe dzieci i młodzieży. Teoria i badania. Warszawa, 54-70. 